\title{
Communicating about Water Security under a Changing Climate
}

\author{
Anna Hurlimann ${ }^{1}$ and Sarah Bell ${ }^{2}$ \\ ${ }^{1}$ The University of Melbourne, Faculty of Architecture Building and Planning hurac@unimelb.edu.au \\ ${ }^{2}$ University College London, Civil Environmental and Geomatic Engineering
}

\begin{abstract}
Summary
Some of the most significant impacts of climate change are likely to be felt in water resources management, but climate change is not the only uncertainty facing water managers and policymakers. The concept of water security has emerged to address social, economic, political, and environmental factors, as well as the physical determinants of water availability. There are significant challenges for communicating about water security under a changing climate. Water security shares many of the characteristics of climate change with regards to communication. It is a complex concept involving interactions between dynamic human and natural systems, requiring public deliberation and engagement to inform political debate and to facilitate behavioral and cultural change. Knowledge and values about water and climate change are communicated through material experiences as well as through language. Communication about water security and climate change takes many forms, which can be characterized as five key modes-policy, communication campaigns, media, cultures, and environments. More effective communication about climate change and water is needed across these different modes to support meaningful participation and deliberation in policy decisions by a wide range of stakeholders. Integrating climate change into communication campaigns about water security provides opportunities to challenge and reframe traditional formulations of the role of water in society and culture and how to manage water in human settlements, the economy, and the environment. The central challenge for communicating the impacts of climate change on water scarcity lies in the complex interactions between society, policy, technology, infrastructure, the economy, and the environment in modern water systems. Different modes of communication are useful to enable public and stakeholder engagement in understanding the issues and making decisions about how to ensure water security in a changing society and environment.
\end{abstract}

Keywords: water, climate change, communication, water security, water scarcity, drought, infrastructure, water resource management

This is a prepublication version (accepted proof) of: Hurlimann, A., \& Bell, S. (2019). Communicating about water security under a changing climate. In Oxford Research Encyclopedia of Climate Science. Oxford University Press.

doi: http://dx.doi.org/10.1093/acrefore/9780190228620.013.419 


\section{Introduction}

Water is a critical natural resource. Human life depends on an adequate and safe supply of water for survival and to support thriving economies, societies, and environments. Yet in some locations population growth and development have placed increasing pressure on water resources and the environments which they support. These pressures have had significant impact on populations. Climate change is predicted to have a significant impact on available water resources in many locations. Yet the challenges to water management are not globally uniform. Research indicates that increasing water scarcity in many regions will be driven by increasing demand for water, rather than decreasing supply due to climate change (Vorosmarty et al., 2010). Additionally, the experience of insecure water supply for the world's poorest people is most often the result of political and economic failure, rather than hydrological constraints (Arnell, 2004; Zeitoun et al., 2016). Thus the concept of water security has emerged partly in recognition of the need to address social, economic, political, and environmental factors, as well as physical determinants of water availability. Water security aims to ensure adequate, sustainable, and equitable access to water to support livelihoods and development in a context of environmental uncertainty.

Water security serves as a focal point for this article, which addresses the complexity of communicating about climate change and its relationship to short- and medium-term water shortages during periods of drought and longer-term trends of increasing water scarcity. The concept of water security provides a wider social, economic, and political context in which to analyze and communicate the physical phenomena of changing precipitation patterns as a result of climate change and the implications for water supply management.

Water will be an increasingly important resource for humans under a changing climate given its contribution to facilitating adaptation to anticipated changes (e.g., assisting with urban cooling and protecting human health in heat waves). Modern cities, particularly those in developed nations, have sophisticated and highly technological systems of water supply management and delivery. These have been designed using historical water records with little or no consideration of climate change impacts. Thus, under a changing climate, there is a potential vulnerability of these systems and the communities that rely upon them. These characteristics of water systems and their vulnerability to climate change make communication an important consideration. Communication, defined broadly, can be considered the 
"transfer of information" (Steinfatt, 2009 p. 2). The aim of this article is to critically discuss the application of "communication" in the climate change and water fields and highlight the challenges for communication of water security under a changing climate. To achieve this aim, it begins by providing an overview of the characteristics of modern water systems and key issues related to water security. This will aid the understanding of water communication needs and how these differ from communication needs in other sectors. The article then discusses key climate change communication issues and the communication implications for water security under a changing climate. Future needs for communicating about water security under a changing climate are identified.

\section{Water Security and Climate Change}

Technological advances to safely and efficiently deliver water to urban populations have been critical to the expansion of human populations and the development of modern societies. However, population growth and improved standards of living are associated with higher environmental impacts, including for water quality and quantity (Millennium Ecosystem Assessment, 2005a). We begin here with a discussion of key water issues, including water infrastructure and its expansion over time, and projected climate change impacts on water, including the potential implications for water security.

\section{Water Infrastructure}

Conventional water resources planning has focused on building infrastructure (e.g., dams and transfer pipes) to meet demand within long-term hydrological variability. The design of the water systems that dominate urban landscapes were predicated on historical hydrological data that is increasingly inappropriate given climate change challenges and socioeconomic changes (Harris, Quinn, \& Bridgeman, 2014). As demand forecasts and hydrological variability are becoming more uncertain, water resource planning is becoming more complex, requiring multidisciplinary expertise and wider stakeholder engagement. In times of drought (“temporary lack of water compared to normal conditions" [Van Loon et al., 2016, p. 3637]), water managers typically engage customers and stakeholders around necessary responses to reduced water availability (e.g., restrictions to water use). Even in the most extreme droughts, water infrastructure in developed countries largely continues to deliver uninterrupted supply. 
In many instances, further infrastructure has been provided in response to this uncertainty, including seawater desalination (Lattemann, Kennedy, Schippers, \& Amy, 2010), stormwater harvesting (Roy et al., 2008), and wastewater recycling (National Research Council, 2012). As a result, water infrastructure systems and the experience of uninterrupted supply communicate the efficacy of engineering-led, technological solutions that mediate between socioeconomic systems and hydrological systems. Yet there is potential for these responses to be maladaptive (Barnett \& O’Neill, 2010; Huntjens et al., 2012). These systems typically require significant amounts of energy to treat these alternative water sources and deliver them to the communities which will benefit from them. In most instances globally, they are contributing to the problem of climate change through increased greenhouse gas emissions. An additional challenge is that conventional infrastructure dissociates water use from water availability and affirms expert-led decisionmaking, delivering water to users on demand. There has been increasing criticism of these supply side approaches to addressing climate change and future water challenges (Aerts \& Droogers, 2012; Isler, Merson, \& Roser, 2010; Pahl-Wostl, 2007). Research regarding community attitudes to these supply side solutions to water crisis find levels of support differ between communities (Hurlimann \& Dolnicar, 2016) and at different points in time and water availability (Price et al., 2010).

An increasing awareness of the need to consider the interactions between human use of water and the impacts for ecosystems gained momentum in the 1990s (Falkenmark, 2003; Gleick, 1998). A greater understanding of water in a holistic manner is emerging to address environmental needs for water, to maintain ecosystem services that are important for ecological function, and supporting human life and livelihoods. A greater awareness now exists of the need to consider the relationship between green and blue infrastructure (e.g., natural resources related to ecology and water) and their benefit for human health, wellbeing, and the potential to assist climate change adaptation and mitigation (Kazmierczak \& Carter, 2010). The recognized need for a minimum level of "environmental flows" in rivers to provide an allocation of water for environmental purposes is occurring in some locations (Falkenmark, 2003; Goss, 2003; Jones et al., 2002). Yet under extreme drought and water scarcity conditions, human need for water has led to cuts in committed environmental flows (Grant et al., 2013).

\section{Integrated Water Resources Management}


Given the increasing complexity of water resource management and acknowledging the limitations of the existing water paradigm, research and policy in many contexts has advocated the concept of integrated water resources management (IWRM). This can be defined as "a process which promotes the coordinated development and management of water, land and related resources in order to maximise economic and social welfare in an equitable manner without compromising the sustainability of vital ecosystems" (Global Water Partnership, 2004, p. 7). In international discourse, the concept of IWRM was first promoted at the 1977 Mar del Plata United Nations (UN) Conference on Water, and it was confirmed as part of Agenda 21 at the 1992 UN Conference on Environment and Development. IWRM has been proposed as the foundation for adaptive management of water, enabling social learning in the context of climate and environmental change (Pahl-Wostl et al., 2007). It has been criticized for depoliticizing water management and reenforcing the status of powerful stakeholders in water management (Fischhendler \& Heikkila, 2010; Zeitoun et al., 2016). Stakeholder engagement and participation is a central element of IWRM to identify and manage demands and impacts on water resources and water quality. Communicating and agreeing upon underlying science, including the longer term impacts of climate change, is important in supporting good engagement and decision-making.

\section{Water Security}

In 2012 the Organisation for Economic Co-operation and Development (OECD) forecast that, based on current trends, by $205040 \%$ of the world's population will be living in water catchments that are under severe water stress (OECD, 2012). In the second half of the 20th century demand for water grew twice as fast as the population. This is largely due to increased agricultural production, as agriculture accounts for approximately $70 \%$ of global water withdrawals. The OECD forecasts that by 2050 the proportion of water used by agriculture will decline, as domestic and industrial water use increases at a higher rate, particularly demand for cooling thermal power stations. Climate change is likely to make water resources management more complex, but it is only one factor in determining water security (Vorosmarty et al., 2010).

Multiple definitions of water security reflect broader or narrower constructions of the role of water in society and politics (Cook \& Bakker, 2012). It is defined by the UN University Institute for Water, Environment and Health (2013) as 
the capacity of a population to safeguard sustainable access to adequate quantities of acceptable quality water for sustaining livelihoods, human well-being and socio-economic development, for ensuring protection against water-borne pollution and water-related disasters, and for preserving ecosystems in a climate of peace and political stability. (p. vi)

Zeitoun et al. (2016) reviewed water security literature and identified "reductionist" and "integrative" approaches. Reductionist approaches to water security include risk-based approaches that align with dominant policy discourse and seek to reduce uncertainty surrounding water resources management. Integrative approaches move beyond IWRM to address issues of equality of access and a more explicit recognition of the political nature of water resources management and decisions. In adding complexity, integrative approaches may be more difficult to communicate and translate to policy and action, and they require more open, deliberative processes for decision-making than conventional water management.

\section{Climate Change Impacts for Water Security}

Some of the most significant impacts of climate change are likely to be felt in water resources management, but, as discussed earlier, climate change is not the only uncertainty facing water resource managers. Climate change is one of many interacting factors increasing the uncertainty associated with managing water infrastructure systems. Changing patterns of precipitation will alter the availability and reliability of water for human use and ecosystems, but attributing the causation of different factors influencing water scarcity is complex and will vary between regions (Bates, Kundzewicz, Wu, \& Palutikof, 2008; Gosling \& Arnell, 2016). Reduced overall average precipitation could contribute to water insecurity in some regions; greater variability could lead to more frequent, prolonged and intense droughts; and significant impacts on water availability are forecast in glacier-fed river systems (Bates et al., 2008; Intergovernmental Panel on Climate Change, 2014). Some areas will experience an increase in flood frequency and/or intensity, further complicating efforts to communicate the impact of climate change on water security. Climate change impacts will have direct and indirect impacts on societies and the environments and economies on which they depend. Climate change is likely to impact on demand for water as well as limit supply, and climate change impacts on the economy will have secondary impacts on water demand and availability (Arnell, 2004. This article addresses the challenge of communicating about water security under a changing climate, within complex contexts of water infrastructure, policies, consumption, and culture. 


\section{Communicating About Water Security}

Research into water communication has been limited but expanding since the 2000s. This limited focus can be attributed to the dominance of the engineering and technology disciplines in managing water, in addition to a poor integration of social science knowledge in water management (Herve-Bazin, 2014). Herve-Bazin in her book on water communication observes that research on water communication has been fragmented, and that which has been conducted has included work in the fields of marketing, perceptions, representations and anthropological origins, discourse analysis, and media coverage (p. 12). Communication about water in practice takes many forms, given the diverse nature of water management. As defined by Herve-Bazin:

"Water communication applies to all forms of communication on fresh water resources. It includes processes, interactions, discourses, messages, logos, campaigns, codes and rituals disseminating information, symbols, perceptions and values on water resources" (p. 1).

Given the limited nature of water communication as a direct field of research, Herve-Bazin (2014 pp. 19-31) provides an overview of broader contributions to water communications. These influences include

- Environment and sustainable development communication fields — which are closely related to water resources;

- Water's social and cultural representations - through religion and cultural symbols;

- Health communication - which has developed from communication of public health issues related to water and public perceptions of water;

- Risk communication — which has influenced communications on water-related risk, including water quality and quantity, and discourses surrounding water risks;

- Rights, legal aspects, and political communication — including of the right to water access and public and political engagement for water policies;

- Public communication related to responsible management of water resources (e.g., by public institutions);

- Scientific communication - how scientific information about water (which is often complex) is communicated to nonexperts (including media coverage of water science, how the public perceives the communication, and the impact on behaviors); and 
- Discourses on cities — which includes discourses on urban water challenges.

Communication about water can take many forms (Herve-Bazin, 2014). Water itself also takes many forms, and so it is important to extend communication of water beyond freshwater resources to include alternative sources such as desalination, water reuse, and localized water recycling and rainwater harvesting. Modes of water communication can be influenced by both private actors (e.g., private companies and individuals at their own initiative) and public actors (e.g., government initiatives) and are both formal and informal. Water knowledge and debates are communicated across time and through policy, technology, and the built environment, as well as through traditional media, social media, and purposive education campaigns.

In Table 1, five key water communication modes are presented and explained, with their connections to communication literature made explicit. The discussion on water communication provided in this section draws upon both direct and indirect literature from the field of water management and communication. The discussion is organized into the modes of water communication highlighted in Table 1: policy, communication campaigns, media, culture, and the environment.

\section{Policy}

Governments communicate about drought and water scarcity to communities in multiple ways. These include through public statements about water and climate and through the policies they implement to support their vision for water. The way drought is defined by governments communicates their understanding of drought and its relationship to human activities (Hayman \& Rickards, 2013; Xiong, Wei, Zhang, \& Wei, 2016). In some countries, the social discourse surrounding drought has treated it as a natural disaster, rather than as an event within normal climate variability (Botterill \& Fisher, 2003). This discourse communicates particular information about drought which shapes public perceptions. Government policies in various countries have reinforced this depiction of drought as disaster (e.g., through natural disaster policy for drought relief through financial assistance for farmers; Dolan, 1990; Hayman \& Rickards, 2013; Wahlquist, 2003).

In the international arena, the UN has made various declarations about water to communicate and focus international attention on particular water issues. In 2005, the UN launched an international decade "Water for Health" (Annan, 2005; United Nations, 2003) to increase the international focus on achieving 
development targets for water and sanitation by 2015 and in doing so acknowledged the impact of drought in many places. In 2010 it declared that water was a basic human right (United Nations General Assembly, 2010) in order to focus the international community's attention on the importance of supporting the equitable provision of water. Also influential at the cross-nation level are European Union policies about water (e.g., European Commission Environment, 2008; European Environment Agency, 2012a, 2012b), which seek to sustainably manage human demands for water and ecosystems needs. Scholars have highlighted limitations with the existing water and drought policies of the European Union, including a lack of a harmonized approach to drought risk management (Kampragou, Apostolaki, Manoli, Froebrich, \& Assimacopoulos, 2011).

Spatial planning policy and water planning have had limited intersections to date, but their potential to be mutually beneficial is increasingly understood (Carter, 2007; Gober et al., 2012; Hurlimann \& Wilson, 2018). There are many possible spatial planning policy tools (Hopkins, 2001) that can facilitate desired water outcomes. All of these have the potential to communicate desired water outcomes to the community and to set expectations for social and cultural relationships with and behaviors toward water and shape the urban-water relationship in the built environment.

$<$ COMP: INSERT TABLE 1 NEAR HERE $>$

The price of water also communicates. Price sends messages about the value of the resource and the manner in which it should be used, helps direct investment to achieve social and environmental goals, and reduce unnecessary consumption (Hatton MacDonald, 2004; Levin et al., 2002). For example, the price of irrigation water has been found to send an important message about water scarcity for farmers in China (Tang, Folmer, \& Xue, 2013). In many countries and contexts, domestic users of water do not pay for the water they use, and there has been a move to install meters to measure the volume of water used, and to charge accordingly, with demand management benefits (Council of Australian Governments, 1994; Harutyunyan, 2015). Consumption data obtained by utilities can be a source of communication to customers about their consumption and leaks within their water systems (Boyle, Eskaf, Tiger, \& Hughes, 2011; Britton, Stewart, \& O'Halloran, 2013), hence helping to reduce water consumption and water costs. Recycled water is often more costly to produce than drinking water due to additional treatment infrastructure and the transport needed to provide it (Hatton MacDonald, 2004), yet research indicates community unwillingness to pay a higher price given the different perceived quality (Hurlimann, McKay, \& Geursen, 2005). 


\section{Communication Campaigns}

Governments and water authorities communicate about water issues to the community, including directly to their customers and extended stakeholders. Various communication guides have been developed for the water industry to aid their activities (e.g., Mobley, Tatham, Reinhardt, \& Tatham, 2006; Nancarrow \& Syme, 1989). Research has indicated that providing customers with information about water is important. Clear information provision has been found to increase public acceptance of recycled water (Dolnicar et al., 2010; Fielding \& Roiko, 2014) and water conservation behavior (Hurlimann \& Dolnicar, 2010; Trumbo \& O’Keefe, 2001). However, research conducted in Texas by Blanchard-Boehm et al. (2008) relating to the publicly defeated Applewhite Dam and Reservoir project indicates a mismatch in communication between the decision-makers and the public. The authors recommend that authorities in such a situation clearly communicate water risks and solutions, and do so well before a decision has to be made, to facilitate an informed and engaged public. They also suggest a broader range of communication channels, fitting with those used by the community.

A study of a drought relief seed program for farmers in Brazil (de Mello Lemos, 2003) found that government experts felt their information (technocratic approach) was superior to farmers' knowledge. This resulted in a weak acknowledgement of farmers' local knowledge needs and risk. The detailed case analysis suggests that this may lead to the erosion of policymakers' problem-solving ability in the long term. Likewise, a Dutch water study has found that knowledge production between stakeholders and experts and bureaucrats is problematic (Edelenbos, van Buuren, \& van Schie, 2011). The authors suggest this can lead to issues of legitimacy of decision-making and information. The need for technical experts to be mindful of their interaction with communities is also highlighted by the case of a water scarcity forum in north Colorado, where it was found that uninvited interjections by water authorities stifled deliberative processes (Sprain, Carcasson, \& Merolla, 2014). The authors believe training and careful planning can overcome this challenge.

A range of studies have been conducted about the effectiveness of various water campaign communication tools on water attitudes and/or behavior. Visual information about a fictional water scarcity scenario was found to be effective in focusing the decision-making of participants in a workshop in Michigan (Turner, 2016). The study indicates that most participants focused their decision-making on the 
visual cue — which varied across participants. Likewise, in Phoenix, Arizona, Larson and Edsall (2010) investigated the effectiveness of visual information about groundwater management presented in both $2 \mathrm{D}$ and 3D format. They found that different information formats had a different impact for a range of perceptions of water risk magnitude, sources of the problem, and potential solutions. Hence one approach may not fit all messages and populations. Research extends to recycled water, where in Greece Tsagarakis et al. (2007) tested the effectiveness of international standard water recycling labeling versus empirically driven signage. They found that participants' stated intention to use recycled water was higher when the empirically derived signage was used. Further research in this field exists (but is outside the scope of this article) and indicates the potential role visual cues can play in water campaigns.

\section{Media}

Communication about water issues can occur through a range of media in a more complex communication landscape than existed before the 2000s. Given the advent of social media, communication about water can occur through multiple channels by a range of actors. For example, social media played an influential role in public debate surrounding a referendum on potable use of recycled water in Toowoomba, Australia (Hurlimann \& Dolnicar, 2010). Ishida and Bledsoe (2015) conducted an analysis of Twitter use by three sources (governor's office, an environmental nongovernmental organization, and an environmental reporter) during a significant period of drought in California in 2014. They found that Twitter was used to frame the drought and for agenda setting — which was different for each actor. The authors also found that there was an overall focus on updating the community about drought, long-term solutions, and environmental impacts, rather than a sense of urgency. Water authorities have been increasing their use of nontraditional media more recently to engage communities in demand management practices in times of need. For example, authorities in the Australian cities of Brisbane (Walton \& Hume, 2011) and Melbourne (Government of Victoria, 2008) have been successfully using social media in addition to a range of other communication media to engage residents in water use reduction at times of water scarcity. Additionally, the Tap campaign in Sydney has been successful in enhancing information about the safety and benefits of drinking tap water (Sydney Water, 2014).

Throughout time, an important communication medium has been mass media (e.g., newspapers and television; Jamieson \& Campbell, 1992; Soroka, 2002). In general, media has been found to be influential in 
shaping public opinion and policy. In considering the portrayal of drought in the mass media across temporal scales, a dominant discourse of climatic drivers is evidenced. Early media portrayal of drought in the 1800s in Australia, New Zealand, and the Pacific depicted drought as a natural menace causing havoc for populations (Garden, 2009) and likewise in America as an "enemy" (Dolan, 1990). Wahlquist (2003) analyzed the coverage of drought in the Australian media in the 1990s and found that media coverage of drought was presented in a manner that was removed from reality. Drought was presented as a disaster and a battle for farmers, with imagery of suffering receiving dominant attention. Wahlquist found that such a portrayal influenced government policy responses to drought that were unhelpful and called for a new portrayal of drought in the Australian media — to embrace the inherent nature of drought, which is being considered by government (Hayman \& Rickards, 2013).

Further, an analysis of the media coverage of the onset of drought in Sydney and London found the existence of different discourses (Bell, 2009). Bell found that in Sydney the media presented drought as a natural feature of the city's environment, with the community having a moral duty to contribute to managing these conditions. By contrast, Bell found that the London drought was portrayed by the media as a failure of the city's private water utility to invest in necessary infrastructure to cope with such conditions (e.g., fixing widespread leakage). Bell's analysis found that the public understood drought to be a cultural and institutional event, in addition to an event that was hydrological and technical.

Hurlimann and Dolnicar's (2012) analysis of media coverage of water issues in the Australian media in 2008 found that drought dominated the coverage of water issues in the media, accounting for $56 \%$ of articles in their sample. For the whole sample, the authors found limited inclusion of views from multiple stakeholders, low impartiality, and limited support of information with scientific evidence. A long-term media analysis of the coverage of water in The People's Daily in China by Xiong et al. (2016) found that the dominant topics and discourse changed over time. While discussion of drought occurred across the whole time period, it was the dominant topic from 1946 to the 1980s along with flooding. Their analysis found a dominant voice of government through these articles with little portrayal of public views. Agencies at all levels of influence use press releases to communicate about water, ranging from international levels, for example the UN's warning about a looming water crisis (United Nations Educational Scientific and Cultural Organisation, 2002); to national governments, for example Singapore’s Public Utilities Board (2017) 
communicating about the opening of its fifth recycled water plant; to subnational levels, such as the Toowoomba City Council (2005) communicating about its plans for potable use of recycled water.

\section{Culture}

Water is not simply an ecological and economic asset; it is also a cultural asset—closely tied to beliefs, customs, and behaviors (Shiva, 2002). For many indigenous communities across the globe, water holds religious and spiritual significance (Getches, 2005; Nursey-Bray \& Arabana Aboriginal Corporation, 2015; Shiva, 2002). Hence water cultures communicate expectations about water use, water beliefs, and water values. As acknowledged by Shiva (2002), "water has been central to the material and cultural well-being of societies all over the world," the "matrix of culture" (p. 1). Across the globe the privatization and corporatization of water has been a significant cultural change. This has resulted in clashes across the globe, including in Jaipur, India — a clash between the culture that sees water as sacred for preservation of life versus a culture that sees water as a commodity, with a corporate right to own and trade it (Shiva, 2002). Likewise, there are conflicts in other cultures and contexts between expectations of daily water use and the demands placed on centralized infrastructure systems that are rigid and the water conservation requirements imposed during times of drought. In an Australian study of cultural aspects of domestic water use, Allon and Sofoulis (2006) concluded that in order for water management approaches such as water use restrictions to work, the cultural importance of water use needs to be better understood (i.e., the cultural importance of showering and of watering outdoor private landscapes). The authors concluded there would be greater potential for water use consumption to change if water narratives were reimagined to move away from what they termed "Big Water," the technocratic approach to water management.

Water cultures can develop over time in response to larger cultural and political circumstances. In Singapore, a city-state with a desire and need for water self-sufficiency, the Singapore International Water Week is held biennially. Singapore is becoming known as a "global hydrohub," or a source of water expertise and technology that is exported globally (Barlow, 2007), given Singapore's unique water supply characteristics and knowledge capacity. Singapore's Public Utilities Board has implemented the “Active, Beautiful, Clean, Waters" (ABC Waters) program, which aims to transform Singapore's water bodies and associated parks into enjoyable places, to engender a cultural value on water resources and their ecological services (Tortajada, Joshi, \& Biswas, 2013). Singapore uses potable recycled water, "NEWater," to 
supplement its drinking water supply. In engaging the community about NEWater, the Public Utilities Board embarked on active community engagement programs, including investment in water's recreational cultural value on the island through ABC Waters (Tortajada et al., 2013). Other countries also have large-scale water events on the international water calendar that celebrate water, culture, and innovation. This includes Sweden, with its annual Stockholm Water Week hosted by the Stockholm International Water Institute supported by the Swedish Royal Family. On a different scale, many towns and cities across the world hold regular river festivals, celebrating directly or indirectly rivers and the associated culture.

Individual water habits and shared practices and norms communicate about the role of water in everyday life. Water has been characterized as "inconspicuous consumption” by sociologist Elizabeth Shove (2003), who positions water using practices within systems of technology and infrastructure that constrain and enable particular patterns of water use. Water consumption is embedded in everyday practices of personal hygiene and pleasure and is hidden within modern appliances such as dishwashers and washing machines. As Hawkins (2006) posits, the normalization of bathrooms has changed habits and responsibilities relating to water use and management of waste. Infrastructure and technology transform our water and related habits and communicate a specific role for water and the process through which it is used. Cultural norms and practices of cleanliness, gardening, and housekeeping evolve with technology and infrastructure. Cultural expectations about frequency of showering and laundry communicate the relative importance of personal cleanliness as an element of social acceptability compared to water conservation. Changes in garden design and gardening practices toward more drought-tolerant plants and irrigation from nonpotable water sources communicate the importance of adapting to resource scarcity (Allon \& Sofoulis, 2006). Water-using practices and habits have been found to differ between locations. Studies comparing water use in distinct locations have found different water use and conservation practices and attitudes (Elizondo \& Lofthouse, 2010; Gilbertson et al., 2011; Richter \& Stamminger, 2012). These are somewhat mediated by different water technologies, appliances, and culture. The communication implication is that no one message will fit all contexts.

Cultural water practices and meanings are historically transmitted. This historically transmitted information influences current and future water communication and actions. Water histories can be communicated in both a technical and nontechnical manner. For example, technical meteorological records collected at national and subnational levels by government bodies communicate about past climatic 
conditions, which have coalesced to influence past drought and water scarcity conditions. Historical records of rainfall, temperature, and aridity provide information about the past from which to predict current and future drought conditions. These records typically form the basis of water management planning. Such records are usually available to the public. They are also drawn upon in the present when reporting and comparing current drought conditions (e.g., media accounts often say "today was the highest temperature recorded since ...”).

The communication of water histories can be informal too, for example through family histories passed down from generation to generation, and often includes associated water behaviors. In many instances, innovative water cultures continue, albeit "stuck" in the sociotechnological water system, as evidenced in Allon and Sofoulis' (2006) Australian study. Likewise, a connection to the reality of a lack of water can starkly contrast the acceptance of an alternative water source (e.g., potable water reuse) should the need to relocate arise because of severe water shortages (Hurlimann \& Dolnicar, 2011).

\section{Environment}

Natural and built environments communicate about water nonverbally. Open space and green and blue spaces (or the lack thereof) in cities communicate the value of water and its place in cities. Built infrastructure for water management communicates human domination and control of water and implies a certain level of water security. Technology and infrastructure were central to communicating the logic of 20th-century water management described earlier in the article. The construction of large dams and reservoirs, distribution networks, treatment works, and sewerage systems has been the basis of modern water management, delivering a continuous supply of freshwater to meet demand from agriculture, industry, and the domestic sector. These systems were based on the assumed capacity of engineering systems to control water, to expand to meet growing demand, and to provide sufficient storage and connectivity to overcome seasonal and interannual variability. The resulting message that water is an endless resource was effectively "baked-in" to water infrastructure and water-using technologies (Sofoulis, 2005). In times of drought, many water utilities communicate to users the need to conserve water as a scarce resource, yet water infrastructure keeps delivering a continuous water supply (Sofoulis, 2005) in many instances.

A city's built form is a result of both private and public investment in infrastructure and built and natural capital that is a shared public and private asset. It communicates a collective human position and 
relationship with water and the environment that evolves over decades. Water and nature influence the development of cities, shaping their location and form. Likewise, a city's built and natural form can communicate a population's attitudes and relationships with water and related ecosystems. One of the most significant drivers of ecosystem change is land use change, including the physical modification of rivers and water withdrawal (Millennium Ecosystem Assessment, 2005a). Urbanization and the changes to water and associated ecosystems that have occurred remove residents from the city's ecological state and natural processes (Millennium Ecosystem Assessment, 2005b). Due to their impervious surfaces, cities result in increased runoff, reduced groundwater recharge, and less evapotranspiration, with natural water courses often altered through channelizing (Hough, 2004). This communicates a human dominance and control of water. Similarly, the process of urbanization has led to fewer opportunities for plants, trees, and ecology (Hough, 2004). Yet, as recognized by Presland (2008), while these natural water characteristics can be hidden, it is likely they will reemerge over time (e.g., ephemeral creeks and streams running during and after certain rainfall events, even in urbanized environments).

\section{Communicating about Climate Change and Water Security}

Communication about climate change has developed in volume and sophistication since the concept of anthropogenic climate change was first on the public agenda in the 1980s (Moser, 2010). Moving from a fact-based scientific problem in the early years to one that reaches all sectors of society has seen climate change communication increase in complexity (Moser, 2010). Like the field of water, for climate change in the early phases, many of the communicators of climate change were the scientists conducting the research—who did not necessarily have skills and technical expertise in communication (Moser, 2010). While "climate change" is a term used in mainstream society, research indicates that many people do not have much knowledge about it (Brechin, 2003; Whitmarsh, 2009).

Communicating about climate changes is made difficult by the complexity and uncertainty associated with the physical phenomena and the science that describes it; its deep connections to social, economic, political, and cultural life; and the abstract construction as something that may happen in the future, with different consequences in different places and with invisible causes (Moser, 2010; Nerlich, Koteyko, \& Brown, 2010). Moser outlines that the implications of these challenges for climate change communication is 
that "lay audiences need to receive ample, clear, sufficiently strong, and consistent signals that support the necessary changes" (p. 36).

Research conducted in the UK has advocated for the need to go beyond communication campaigns that seek to foster greener attitudes and behavior (Ockwell, Whitmarsh, \& O’Neill, 2009). In order to support greater engagement of the public with climate change, it is advocated that people must also care about it and be motivated to take action — seeing engagement as having three key components: cognitive, affective, and behavioral (Lorenzoni, Nicholson-Cole, \& Whitmarsh, 2007; Ockwell et al., 2009). Ockwell et al. identified both individual-level and society-level barriers to engagement with climate change and stated that only by addressing both can the necessary wide-scale behavior change be reached. Doing so would require regulation of climate change behaviors and grassroots engagement. Research indicates that experience of climate change impact can facilitate attitudes and intended behavior that is necessary to address climate change (e.g., Brody, Zahran, Vedlitz, \& Grover, 2008; Palutikof, Agnew, \& Hoar, 2004).

In thinking about how existing climate communication could be improved, Nerlich et al. (2010) highlight some key actions. These include conducting empirical research to plan and evaluate communications; looking beyond the typical models of the relationship between scientific and lay knowledge to embrace the complex and culturally determined global to local impact of climate change; and acknowledging that there is no such thing as an effective communication strategy per se — that framing of messages and knowledge of what they should say should be informed by ongoing studies of community perceptions (Nerlich et al., 2010, p. 106). Moser (2016) finds that a number of persistent challenges remain: "a superficial public understanding of climate change, transitioning from awareness and concern to action, communicating in deeply politicised and polarised environments, and dealing with the growing sense of overwhelm and helplessness" ( p. 345). Moser identifies the need for greater interaction between climate communicators and practice and a series of challenges in the field, including how to know what topics to focus on and questioning the role of communication in a rapidly changing world.

Water security is a key topic for climate change communication, and climate change is a key issue for water security communication. Water security shares many of the characteristics of climate change with regards to communication (detailed earlier). Hydrology and meteorology describe complex physical phenomena. Water security is highly contingent upon political, economic, and social actions and decisions and is unevenly distributed in space and time. Communication about the impacts of climate change on water 
security therefore requires an understanding of how people use water; how water use has changed over time; how water use is influenced by culture; and the role of infrastructure, technology, and the built environment in mediating relationships between society, culture, water, and the environment. We now turn to consider the implications of climate change for the five water communication modes discussed earlier, building on this discussion.

\section{Policy}

Communication about climate change and its impacts on water security are occurring in technical discourse and strategic water policy documents written by governments and water authorities in some jurisdictions (e.g., Department for Environment Food and Rural Affairs, 2011; Government of Victoria, 2013), but at present this is not in a form that is easily accessible to the public. More effective communication about climate change and water is needed across different modes to support meaningful participation and deliberation in decisions by a wide range of stakeholders, including the public and marginalized groups. Informal modes of communication support wider engagement with climate change and water and cross both public and private realms through culture, the city, technology, and everyday life. However, as advocated by many climate change communication experts, there is a need to move beyond the traditional informationdeficit models (Moser, 2010; Nerlich et al., 2010; Ockwell et al., 2009). Engaging citizens and water users in planning for resilient water systems should enable consideration of a wider range of adaptation options, including demand reduction, alternative water supplies, urban design and planning, economic reform, and new infrastructure options. The public should represent genuine stakeholders in the decision-making process. Additionally, as advocated by Ockwell et al., there may be a role for communication to foster demand for regulation to address climate change/water issues.

\section{Communication Campaigns}

Enhancing resilience of urban water systems to climate change requires adaptation to underlying trends and extreme events. Campaigns can raise community awareness of these issues and influence attitudes. Integrating climate change into discourse about water security provides opportunities to challenge and reframe traditional formulations of the role of water in society and culture and how to manage water in 
human settlements, the economy, and the environment. Global discourse related to water scarcity as a physical issue draws attention away from the economic, social, and political factors that determine access to water and water and food security (Allan, 2005). There is also a danger of miscommunication about water that could reinforce reductionist water security and conventional supply side solutions by emphasizing physical scarcity at the expense of sociotechnical and political factors. Communication campaigns can be carefully designed to address these issues in a locally relevant context.

\section{Media}

As communication media further develops over time, the potential to engage the community in issues surrounding climate change and water security will develop in increasingly interesting and engaging ways. Authorities will need to be proactive in monitoring these forms to ensure that the accurate messages are conveyed to the public, particularly in forums that they do not control. There is an often-cited dominance of scientific forms of communicating about drought and climate change impacts (Graffy, 2006; Jarvis, 2013; Sivakumar, 2011). Hence, it would be beneficial to explore how different forms of media could be used to communicate water histories into the future to encourage and inform community participation in decisionmaking. This would provide a link to past simple, innovative behaviors that were extant prior to large-scale water technological innovations.

\section{Culture}

Culture and its celebration of water will continue to adapt to environmental changes including climate change. These will serve as important reference points for adaptation. It is now understood that historical records alone are insufficient to plan for future water security given the climate changes that are occurring and will continue to occur into the future (Harris et al., 2014). In a large-scale Australian study about cultural perceptions of climate change, Leviston and colleagues (2014) found that a visual image of drought was strongly associated with climate change, more so than other comparable studies in other countries. However, in a follow-up study published in the same article, Leviston et al. found that Australian participants understood that drought was an issue broader than climate change. These perceptions may well be influential toward the cultural shift in water use that has been observed by numerous Australian 
researchers (Allon \& Sofoulis, 2006; Askew \& McGuirk, 2004; Head \& Muir, 2007). Water cultures drive water behavior and, as these studies show, a largely collective acknowledgement of the need to use water wisely, particularly in times of drought. Research in small Australian communities about future sea level rise found that the local residents temporally situated their experiences of flood and change by "extending the present and past into an imagined future" through "time stories" (Fincher et al., 2014, p. 209). They did not deny climate change would occur but rather viewed it as a continuation of their everyday experiences-in stark contrast to scientists and decision-makers removed from the place. The consideration of "time stories" could be useful for consideration in communicating about climate change and water security.

\section{Environment}

An example of environmental water communication under a changing climate is that of Melbourne, Australia. During the first decade of the 2000s, the city faced significant drought conditions. Drought conditions paired with the urban heat island effect (Coutts, Tapper, Beringer, Loughnan, \& Demuzere, 2013) due to increased urbanization and climate change resulted in significant urban ecology impacts. Urban design guides and strategies began to acknowledge the problematic relationship between engineered water systems and urban life. Melbourne's prolonged drought period resulted in water use restrictions. These combined to result in "irreversible decline for many trees," resulting in the predication that over $25 \%$ of trees in the city will be lost in the following decade (City of Melbourne, 2012, p. 6). As a result the city has produced and is implementing a comprehensive Urban Forest Strategy to address the issue, including the consideration of alternative water sources to ensure the health of the existing and future trees and vegetation (City of Melbourne, 2012). This links with the city’s strategic water policy, Total Water Mark City as a Catchment (City of Melbourne, 2009b), and climate change policy, Climate Change Adaptation Strategy (City of Melbourne, 2009a). Specifically it links to local urban planning policy to influence water-sensitive design in the city (City of Melbourne, 2013) through private development and through council activities to seek out opportunities for rain gardens and other water-sensitive design options. These existing and changing urban forms communicate a different message to the community about water and humans' relationship with it. This is one example of the complex relationship between drought, climate change, management strategies, and communication. Lessons have been learned from these experiences to implement change to ensure a more resilient future. 


\section{Future Needs}

In many areas of the world, increasingly variable climatic events will be experienced, leading to longer periods of drought and higher intensity rainfall. Climate change will have a necessary and significant impact on the current built form of human settlements, the sources of water drawn upon and used by communities, and how water is distributed between human and nonhuman water users. Effectively communicating the full range of options for water system adaptation to climate change requires long-term engagement with the public and stakeholders. Consideration and use of a range of communication modes (Table 1) would be beneficial.

Recent experience of water resources planning in response to drought and long-term forecasts of water scarcity have focused on engaging stakeholders and the public around a preferred option for a new water supply. For instance, referenda in the United States and Australia propose investment in new dams or water reuse schemes. This approach reinforces the role of infrastructure as mediator between the climate and society, presenting specific options to expand supply rather than engaging the public and stakeholders in wider discussion about how to adapt to changing rainfall patterns and how to build resilience to drought. In the UK, water companies are obliged to engage customers in water resources planning, presenting options for managing supply-demand balances and allowing discussion about costs, benefits, and risks. However, this remains focused on water supply utilities, which constrains options within nonnegotiable service standards, and misses wider opportunities for integrating water managing with urban planning, building design, economic activity, demographic change, and other factors outside the control of water companies. In this context climate change is communicated as one of many factors included in the calculations that determine supply-demand balances, with deficits to be met through a limited range of infrastructure and demand management options.

There is a need for more holistic communications about climate change impacts for water security. Without policymakers or the community fully understanding the driving forces for climate change, and the impacts that this will have on water resources, it will be more difficult to transition to a well-adapted water future. Without communicating the necessity of addressing climate change and ways to reduce it, and the need for a new water ethic, the problems faced will only become more complex. Mitigation of climate change is necessary to contain the water challenges the world will face. Likewise, clear communication of 
the changes to hydrological conditions that have occurred and will continue to occur into the future due to climate change is vital in order to explain the adaptation measures sought. Hence, we suggest that a holistic communication agenda is needed for the water industry in light of current and future water/climate changes. We anticipate that this will facilitate a well-adapted approach to water security that is not maladaptive, with bipartisan support, ensuring fair and equitable outcomes, an important part of climate change adaptation. Further detailed research into communicating about water security and climate change would also be beneficial. It will be important to conduct locally relevant and beneficial research with communities embarking on such change.

\section{Conclusion}

The article positions communication about water security under a changing climate within complex sociotechnical, cultural, and political contexts that shape human relationships with water. Water is but one element impacted by climate change, and climate change is one of many factors driving the need for new approaches to water in policy, infrastructure, and everyday life. Communicating the need for reform of existing water systems may be facilitated by improved climate change communication, and better understanding of water systems may support more effective discussions about the likely impacts and required water adaptation strategies for climate change. Climate change provides momentum for a muchneeded paradigm shift in the way water resources are used and managed, including the way in which communities are engaged in water decision-making.

The central challenge for communicating the impacts of climate change on water scarcity lies in the complex interactions between society, policy, technology, infrastructure, the economy, and the environment in modern water systems. We have discussed the many modes of water communication that interact in complex ways. It is useful for authorities to be cognizant of these when considering the shift to a new water paradigm, and when planning communication strategies. Communicating the need for reform to water management will require a broadened approach to communication in the water industry. Improved communication about climate change is necessary for an informed and engaged water public and policymakers and to facilitate the necessary water system transitions.

\section{Acknowledgments}


Funds to support Sarah Bell's collaborative visit to the University of Melbourne, during which this article was drafted, was provided by a Dyason Fellowship from the University of Melbourne. We thank Holly O’Connell-Paladino for research assistance provided in reviewing literature.

\section{References}

Aerts, J., \& Droogers, P. (2012). Adapting to climate change in the water sector. In F. Ludwig, P. Kabat, H. van Schaik, \& M. van der Valk (Eds.), Climate change adaptation in the water sector (pp. 87-107). London, U.K.: Earthscan.

Allon, F., \& Sofoulis, Z. (2006). Everyday water: Cultures in transition. Australian Geographer, 37(1), $45-55$.

Allan, J. A. (2005). Water in the Environment/Socio-Economic Development Discourse: Sustainability, Changing Management Paradigms and Policy Responses in a Global System. Government and Opposition, 40 (2), 181-199.

Annan, K. A. (2005). Message of the Secretary-General of the United Nations to launch the "Water for Life" decade. https://www.un.org/press/en/2005/sgsm9766.doc.htm

Arnell, N. W. (2004). Climate change and global water resources: SRES emissions and socio-economic scenarios. Global Environmental Change, 14, 31-52.

Askew, L., \& McGuirk, P. (2004). Watering the suburbs: Distinction, conformity and the suburban garden. Australian Geographer, 35(1), 17-37.

Barlow, M. (2007). Blue covenant: The global water crisis and the coming battle for the right to water. Melbourne, Australia: Black.

Barnett, J., \& O’Neill, S. J. (2010). Maladaptation. Global Environmental Change, 20, 211-213.

Bates, B. C., Kundzewicz, Z. W., Wu, S., \& Palutikof, J. P. (Eds.). (2008). Climate change and water. Technical Paper of the Intergovernmental Panel on Climate Change. Geneva, Switzerland: IPCC Secretariat.

Bell, S. (2009). The driest continent and the greediest water company: Newspaper reporting of drought in Sydney and London. International Journal of Environmental Studies, 66(5), 581-589. 
Blanchard-Boehm, R. D., Earl, R. A., Wachter, J. H., \& Hanford, E. J. (2008). Communicating future water needs to an at-risk population: Lessons learned following defeat of the Applewhite Dam and Reservoir Project in San Antonio, Texas. Population and Environment, 29(6), 292-312.

Botterill, L. C., \& Fisher, M. (Eds.). (2003). Beyond drought: People, policy and perspectives. Collingwood, Australia: CSIRO.

Boyle, C. E., Eskaf, S., Tiger, M. W., \& Hughes, J. A. (2011). Mining water billing data to inform policy and communication strategies. Journal of the American Water Works Association, 103, 45-58.

Brechin, S. R. (2003). Comparative public opinion and knowledge on global climatic change and the Kyoto protocol: The U.S. versus the world? International Journal of Sociology and Social Policy, 23(10), 106-134.

Britton, T. C., Stewart, R. A., \& O’Halloran, K. R. (2013). Smart metering: Enabler for rapid and effective post meter leakage identification and water loss management. Journal of Cleaner Production, 54, 166176.

Brody, S., D., Zahran, S., Vedlitz, A., \& Grover, H. (2008). Examining the relationship between physical vulnerability and public perceptions of global climate change in the United States. Environment and Behavior, 40(1), 72-95.

Campbell, C., Smith, E., \& Siesmaa, E. (2011). The educative role of a regional newspaper: Learning to be drier. Australian Journal of Adult Learning, 51(2), 269-301.

Carter, J. G. (2007). Spatial planning, water and the Water Framework Directive: Insights from theory and practice. Geographical Journal, 173(4), 330-342.

City of Melbourne. (2009a). Climate change adaptation strategy. Melbourne, Australia: Author.

City of Melbourne. (2009b). Total watermark: City as a catchment. Melbourne, Australia: Author.

City of Melbourne. (2012). Urban forest strategy-making a great city greener 2012-2032. Melbourne, Australia: Author.

City of Melbourne. (2013). Clause 22.19: Energy, water and waste efficiency. In Melbourne Planning Scheme. Melbourne, Australia: Author.

Collier, M. J. (2009). Culture and communication. In S. Littlejohn \& K. Foss (Eds.), Encyclopedia of communication theory (pp. 280-285). Thousand Oaks, CA: SAGE. 
Cook, C., and Bakker, K. (2012). Water security: Debating an emerging paradigm. Global Environmental Change, 22(1), 94-102.

Council of Australian Governments. (1994). Council of Australian Governments' Communique: Attachment A-Water resource policy. Canberra: Author.

Coutts, A. M., Tapper, N. J., Beringer, J., Loughnan, M., \& Demuzere, M. (2013). Watering our cities: The capacity for Water Sensitive Urban Design to support urban cooling and improve human thermal comfort in the Australian context. Progress in Physical Geography, 37(1), 2-28.

de Mello Lemos, M. C. (2003). A tale of two policies: The politics of climate forecasting and drought relief in Ceará, Brazil. Policy Sciences, 36(2), 101-123.

Dean, A. J., Lindsay, J., Fielding, K. S., \& Smith, L. D. G. (2016). Fostering water sensitive citizenshipcommunity profiles of engagement in water-related issues. Environmental Science \& Policy, 55(Pt. 1), $238-247$.

Department for Environment Food and Rural Affairs. (2011). Water for life. London, U.K.: Author.

Dolan, E. (1990). Drought: The past, present and future enemy. New York, NY: Franklin Watts.

Dolnicar, S., Hurlimann, A. C., \& Nghiem, L. (2010). The effect of information on public acceptance-the case of water from alternative sources. Journal of Environmental Management, 91(6), 1288-1293.

Edelenbos, J., van Buuren, A., \& van Schie, N. (2011). Co-producing knowledge: Joint knowledge production between experts, bureaucrats and stakeholders in Dutch water management projects. Environmental Science \& Policy, 14(6), 675-684.

Elizondo, G. M., \& Lofthouse, V. A. (2010). Patterns of conservation and domestic water use in different water cultures: A comparison between Mexico and the UK. Paper presented at the Proceedings of the 16th Annual International Sustainable Development Research Conference, Hong Kong. Kadoori Institute, 30th May-1st June, pp184-195.

European Commission Environment. (2008). Policy paper: Climate change and water. European Union. European Environment Agency. (2012a). A blueprint to safeguard Europe's water resources. Copenhagen, Denmark: Author.

European Environment Agency. (2012b). Towards efficient use of water resources in Europe. Copenhagen, Denmark: Author. 
Falkenmark, M. (2003). Freshwater as shared between society and ecosystems: From divided approaches to integrated challenges. Philosophical Transactions: Biological Sciences, 358(1440), 2037-2049.

Fielding, K. S., \& Roiko, A. H. (2014). Providing information promotes greater public support for potable recycled water. Water Research, 61, 86-96.

Fincher, R., Barnett, J., Graham, S., \& Hurlimann, A. (2014). Time stories: Making sense of futures in anticipation of sea-level rise. Geoforum, 56, 201-210.

Fischhendler, I., \& Heikkila, T. (2010). Does Integrated Water Resources Management Support Institutional Change? The Case of Water Policy Reform in Israel. Ecology \& Society, 15(1), 1-16.

Garden, D. (2009). Droughts, floods and cyclones_El Ninos that shaped our colonial past. North Melbourne, Australia: Australian Scholarly Publishing.

Getches, D. H. (2005). Defending indigenous water rights with the laws of a dominant culture: The case of the United States. In R. Boelens, D. Roth, B. Deutsch Lynch, \& S. L. Baver (Eds.), Liquid relations. New Brunswick, NJ: Rutgers University Press. p 44-65.

Gilbertson, M., Hurlimann, A., \& Dolnicar, S. (2011). Does water context influence behaviour and attitudes to water conservation? Australasian Journal of Environmental Management, 18(1), 47-60.

Gleick, P. H. (1998). Water in crisis: Paths to sustainable water use. Ecological Applications, 8(3), 571579.

Global Water Partnership. (2004). Catalyzing change: A handbook for developing integrated water resources management (IWRM) and water efficiency strategies. Stockholm, Sweden: Author.

Gober, P., Larson, K. L., Quay, R., Polsky, C., Chang, H., \& Shandas, V. (2012). Why land planners and water managers don't talk to one another and why they should! Society \& Natural Resources, 26(3), 356-364.

Gosling, S. N., \& Arnell, N. W. (2016). Global assessment of the impact of climate change on water scarcity. Climatic Change, 134(3), 371-385.

Goss, K. F. (2003). Environmental flows, river salinity and biodiversity conservation: Managing trade-offs in the Murray-Darling basin. Australian Journal of Botany, 51, 619-625.

Government of Victoria. (2008). Save Water. Target 155. Melbourne: Author.

Government of Victoria. (2013). Melbourne's water future. Melbourne: Author. 
Graffy, E. (2006). Expert forecasts and the emergence of water scarcity on public agendas. Society \& Natural Resources, 19(5), 465-472.

Grant, S. B., Fletcher, T. D., Feldman, D., Saphores, J.-D., Cook, P. L. M., Stewardson, M., ... Hamilton, A. J. (2013). Adapting urban water systems to a changing climate: Lessons from the millennium drought in southeast Australia. Environmental Science \& Technology, 47(19), 10727-10734.

Harris, C. N. P., Quinn, A. D., \& Bridgeman, J. (2014). The use of probabilistic weather generator information for climate change adaptation in the UK water sector. Meteorological Applications, 21(2), $129-140$.

Harutyunyan, N. (2015). Metering drinking water in Armenia: The process and impacts. Sustainable Cities and Society, 14, 351-358.

Hatton MacDonald, D. (2004). The economics of water: Taking full account of first use, reuse and return to the environment (S/03/1474). Canberra, Australia: CSIRO Land and Water.

Hawkins, G. (2006). Shit. In The ethics of waste (pp. 45-70). Sydney, NSW: University of New South Wales Press.

Hayman, P., \& Rickards, L. (2013). Drought, climate change, farming, and science: The interaction of four privileged topics. In L. C. Botterill \& G. Cockfield (Eds.), Drought, risk management, and policy: Decision making under uncertainty (pp. 45-70). Boca Raton, FL: CRC Press.

Head, L., \& Muir, P. (2007). Changing cultures of water in eastern Australian backyard gardens. Social and Cultural Geography, 8(6), 889-905.

Herve-Bazin, C. (Ed.). (2014). Water communication. London, U.K.: International Water Association. Hopkins, L. D. (2001). Urban development: The logic of making plans. Washington, DC: Island Press. Hough, M. (2004). Cities and natural processes (2nd ed.). London, U.K.: Taylor \& Francis. Huntjens, P., Lebel, L., Pahl-Wostl, C., Camkin, J., Schulze, R., \& Kranz, N. (2012). Institutional design propositions for the governance of adaptation to climate change in the water sector. Global Environmental Change, 22(1), 67-81.

Hurlimann, A., \& Dolnicar, S. (2010). When public opposition defeats alternative water projects—-the case of Toowoomba, Australia. Water Research, 44(1), 287-297.

Hurlimann, A., \& Dolnicar, S. (2011). Voluntary relocation — an exploration of Australian attitudes in the context of drought, recycled and desalinated water. Global Environmental Change, 21, 1084-1094. 
Hurlimann, A., \& Dolnicar, S. (2012). Newspaper coverage of water issues in Australia. Water Research, 46(19), 6497-6507.

Hurlimann, A., \& Dolnicar, S. (2016). Public acceptance and perceptions of alternative water sources: A comparative study in nine locations. International Journal of Water Resources Development, 32(4), 650-673.

Hurlimann, A., Dolnicar, S., \& Meyer, P. (2009). Understanding behaviour to inform water supply management in developed nations - a review of literature, conceptual model and research agenda. Journal of Environmental Management, 91(1), 47-56.

Hurlimann, A., McKay, J., \& Geursen, G. (2005). Pricing of drinking water vs recycled water: Fairness and satisfaction. Water, Journal of the Australian Water Association, 32(2), 50-66.

Hurlimann, A., \& Wilson, E. (2018). Sustainable urban water management under a changing climate: The role of spatial planning. Water, 10(5), 546.

Intergovernmental Panel on Climate Change. (2014). Climate change 2014-synthesis report. Cambridge, U.K.: Cambridge University Press.

Ishida, S., \& Bledsoe, M. (2015). Twitter usage in public communication campaigns: Agenda setting and issue framing of the California drought crisis. Paper presented at the International Association for Media and Communication Research, July 12-16, Montreal, Quebec.

Isler, P. L., Merson, J., \& Roser, D. (2010). “Drought proofing” Australian cities: Implications for climate change adaptation and sustainability. World Academy of Science, Engineering and Technology, 70, 351360.

Jamieson, K. H., \& Campbell, K. K. (1992). The interplay of influence: News, advertising, politics and the mass media (3rd ed.). Belmont, CA: Wadsworth.

Jarvis, W. T. (2013). Water scarcity: Moving beyond indexes to innovative institutions. Ground Water, $51(5), 663-669$.

Jones, G., Hillman, T., Kingsford, R., McMahon, T., Walker, K., Arthington, A., . . Cartwright, S. (2002). Independent report of the Expert Reference Panel on Environmental Flows and Water Quality Requirements for the River Murray System. Unpublished manuscript. 
Kampragou, E., Apostolaki, S., Manoli, E., Froebrich, J., \& Assimacopoulos, D. (2011). Towards the harmonization of water-related policies for managing drought risks across the EU. Environmental Science \& Policy, 7, 815-824.

Kazmierczak, A., \& Carter, J. (2010). Adaptation to climate change using green and blue infrastructure: A database of case studies. Manchester, U.K.: University of Manchester.

Larson, K. L., \& Edsall, R. M. (2010). The impact of visual information on perceptions of water resource problems and management alternatives. Journal of Environmental Planning \& Management, 53(3), $335-352$.

Lattemann, S., Kennedy, M. D., Schippers, J. C., \& Amy, G. (2010). Global desalination situation. In I. C. Escobar \& A. Schäfer (Eds.), Sustainable water for the future: Water recycling versus desalination (pp. 7-40). Amsterdam, The Netherlands: Elsevier B.V.

Levin, R. B., Epstein, P. R., Ford, T. E., Harrington, W., Olson, E., \& Reichard, E. G. (2002). U.S. drinking water challenges in the twenty-first century. Environmental Health Perspectives, 110, 43-52.

Leviston, Z., Price, J., \& Bishop, B. (2014). Imagining climate change: The role of implicit associations and affective psychological distancing in climate change responses. European Journal of Social Psychology, 5, 441-454.

Lohman, L. C., \& Milliken, J. G. (1985). Informational/educational approaches to public attitudes on potable reuse of wastewater. Denver, CO: Denver Research Institute, University of Denver.

Lorenzoni, I., Nicholson-Cole, S., \& Whitmarsh, L. (2007). Barriers perceived to engaging with climate change among the UK public and their policy implications. Global Environmental Change, 17(3-4), $445-459$.

Millennium Ecosystem Assessment. (2005a). Ecosystems and human well-being: Synthesis. Washington, DC: Island Press.

Millennium Ecosystem Assessment. (2005b). Fresh water. In R. Hassan, R. Scholes, \& N. Ash (Eds.), Ecosystems and human well-being: Current state and trends (Vol. 1, pp. 165-207). Washington, DC: Island Press.

Milstein, T. (2009). Environmental communication theories. In S. Littlejohn \& K. Foss (Eds.), Encyclopedia of communication theory (pp. 345-349). Thousand Oaks, CA: SAGE. 
Mobley, J., Tatham, E., Reinhardt, K., \& Tatham, C. (2006). Strategic communication planning: A guide for water utilities. Denver, CO: AWWA Research Foundation.

Moser, S. (2010). Communicating climate change: History, challenges, process and future directions. Wiley Interdisciplinary Reviews: Climate Change, 1(1), 31-53.

Moser, S. C. (2016). Reflections on climate change communication research and practice in the second decade of the 21st century: What more is there to say? Wiley Interdisciplinary Reviews: Climate Change, 7(3), 345-369.

Nancarrow, B. E., \& Syme, G. J. (1989). Improving communication with the public on water industry policy issues. Melbourne, Australia: Melbourne and Metropolitan Board of Works.

National Research Council. (2012). Water reuse: Potential for expanding the nation's water supply through reuse of municipal wastewater. Washington, DC: National Academies Press.

Nerlich, B., Koteyko, N., \& Brown, B. (2010). Theory and language of climate change communication. Wiley Interdisciplinary Reviews: Climate Change, 1, 97-110.

Nursey-Bray, M., \& Arabana Aboriginal Corporation. (2015). Cultural indicators, country and culture: The Arabana, change and water. The Rangeland Journal, 37(6), 555-569.

Ockwell, D., Whitmarsh, L., \& O’Neill, S. (2009). Reorienting climate change communication for effective mitigation: Forcing people to be green or fostering grass-roots engagement? Science Communication, 30(3), 305-327.

Organisation for Economic Co-operation and Development. (2012). OECD environmental outlook to 2050. Paris, France: Author.

Pahl-Wostl, C. (2007). Transitions towards adaptive management of water facing climate and global change. Water Resources Management, 21(1), 49-62.

Palutikof, J. P., Agnew, M. D., \& Hoar, M. R. (2004). Public perceptions of unusually warm weather in the UK: Impacts, responses and adaptations. Climate Research, 26(1), 43-59.

Pearce, K. J. (2009). Media and mass communication theories. In S. Littlejohn \& K. Foss (Eds.), Encyclopedia of communication theory (pp. 624-627). Thousand Oaks, CA: SAGE.

Presland, G. (2008). The place for a village: How nature has shaped the city of Melbourne. Melbourne, Australia: Museum Victoria. 
Price, J., Fielding, K., Leviston, Z., Bishop, B., Nicol, S., Greenhill, M., \& Tucker, D. (2010). Community acceptability of the indirect potable use of purified recycled water in south-east Queensland: Final report of monitoring surveys. Brisbane, Australia: Urban Water Security Research Alliance.

Public Utilities Board. (2017, January 18). Singapore's fifth NEWater plant opens. Singapore: Author.

Richter, C., \& Stamminger, R. (2012). Water consumption in the kitchen - a case study in four European countries. Water Resources Management, 26(6), 1639-1649.

Roy, A. H., Wenger, S. J., Fletcher, T. D., Walsh, C. J., Ladson, A. R., Shuster, W. D., . . Brown, R. R. (2008). Impediments and solutions to sustainable, watershed-scale urban stormwater management: Lessons from Australia and the United States. Environmental Management, 42(2), 344-359.

Schuetz, J. (2009). Political communication theories. In S. Littlejohn \& K. Foss (Eds.), Encyclopedia of communication theory (pp. 758-761). Thousand Oaks, CA: SAGE.

Shiva, V. (2002). Water wars: Privatisation, pollution and profit. New York, NY: South End Press.

Shove, E. (2003). Converging Conventions of Comfort, Cleanliness and Convenience. Journal of Consumer Policy, 26(4), 395-418.

Silk, K. J. (2009). Campaign communication theories. In S. Littlejohn \& K. Foss (Eds.), Encyclopedia of communication theory (pp. 184-191). Thousand Oaks, CA: SAGE.

Sivakumar, B. (2011). Water crisis: From conflict to cooperation—an overview. Hydrological Sciences Journal/Journal des Sciences Hydrologiques, 56(4), 531-552.

Soroka, S. N. (2002). Issue attributes and agenda-setting by media, the public, and policymakers in Canada. International Journal of Public Opinion Research, 14(3), 264-285.

Sprain, L., Carcasson, M., \& Merolla, A. J. (2014). Utilizing “on tap" experts in deliberative forums: Implications for design. Journal of Applied Communication Research, 42(2), 150-167.

Sofoulis, Z. (2005). Big Water, Everyday Water: A Sociotechnical Perspective. Continuum: Journal of Media \& Cultural Studies, 19(4), 445-463.

Steinfatt, T. (2009). Definitions of communication. In S. W. Littlejohn \& K. A. Foss (Eds.), Encyclopedia of communication theory (Vol. 1, pp. 296-299). Thousand Oaks, CA: SAGE.

Sydney Water. (Producer). (2014). Sydney Water Tap in ${ }^{\mathrm{TM}}$. Sydney, Australia: Author.

Syme, G. J., Nancarrow, B. E., \& Seligman, C. (2000). The evaluation of information campaigns to promote voluntary household water conservation. Evaluation Review, 24(6), 539-578. 
Tang, J., Folmer, H., \& Xue, J. (2013). Estimation of awareness and perception of water scarcity among farmers in the Guanzhong Plain, China, by means of a structural equation model. Journal of Environmental Management, 126, 55-62.

Toowoomba City Council. (2005). Toowoomba Water Futures Project. Toowoomba, Australia: Author. Tortajada, C., Joshi, Y., \& Biswas, A. K. (2013). The Singapore water story: Sustainable development in an urban city state: Hoboken, NJ: Taylor \& Francis.

Trumbo, C. W., \& O’Keefe, G. J. (2001). Intention to conserve water: Environmental values, planned behavior, and information effects. A comparison of three communities sharing a watershed. Society \& Natural Resources, 14(10), 889-899.

Tsagarakis, K. P., Mellon, R., Stamataki, E., \& Kounalaki, E. (2007). Identification of recycled water with an empirically derived symbol increases its probability of use. Environmental Science and Technology, 41(20), 6901-6908.

Turner, S. P. (2016). Internal and external influences on water resource decision making. Society \& Natural Resources, 29(2), 203-217.

United Nations. (2003, December 23). Resolution adopted by the General Assembly 58/217. International Decade for Action, Water for Life: 2005-2015. New York, NY: Author.

United Nations Educational Scientific and Cultural Organisation. (2002, February 28). UNESCO directorgeneral warns of looming water crisis. New York, NY: Author.

United Nations General Assembly. (2010). Resolution adopted by the General Assembly on 28 July 2010, 64/292: The human right to water and sanitation. https://documents-ddsny.un.org/doc/UNDOC/GEN/N09/479/35/PDF/N0947935.pdf?OpenElement New York, NY: Author. United Nations University Institute for Water Environment and Health. (2013). Water security and the global water agenda: A UN-Water analytical brief. New York, NY: Author.

Van Loon, A. F., Stahl, K., Di Baldassarre, G., Clark, J., Rangecroft, S., Wanders, N., . . Van Lanen, H. A. J. (2016). Drought in a human-modified world: Reframing drought definitions, understanding, and analysis approaches. Hydrology and Earth System Sciences, 20(9), 3631-3650.

Vorosmarty, C. J., McIntyre, P. B., Gessner, M. O., Dudgeon, D., Prusevich, A., Green, P., .. . Davies, P. M. (2010). Global threats to human water security and river biodiversity. Nature, 467(7315), 555-561. 
Wahlquist, A. (2003). Media representations and public perceptions of drought. In L. C. Botterill \& M. Fisher (Eds.), Beyond drought: People, policy and perspectives (pp. 67-86). Collingwood, Australia: CSIRO Publishing.

Walton, A., \& Hume, M. (2011). Creating positive habits in water conservation: The case of the

Queensland Water Commission and the Target 140 campaign. International Journal of Nonprofit \& Voluntary Sector Marketing, 16(3), 215-224.

Whitmarsh, L. (2009). Behavioural responses to climate change: Asymmetry of intentions and impacts. Journal of Environmental Psychology, 29(1), 13-23.

Xiong, Y., Wei, Y., Zhang, Z., \& Wei, J. (2016). Evolution of China's water issues as framed in Chinese mainstream newspaper. Ambio, 45(2), 241-253.

Zeitoun, M., Lankford, B., Krueger, T., Forsyth, T., Carter, R., Hoekstra, A. Y., . . Matthews, N. (2016). Reductionist and integrative research approaches to complex water security policy challenges. Global Environmental Change, 39, 143-154.

Table 1.

Modes of Water Communication

\begin{tabular}{|c|c|c|c|}
\hline $\begin{array}{l}\text { Communication } \\
\text { Mode }\end{array}$ & Explanation & $\begin{array}{l}\text { Relationship to Communication } \\
\text { Theory }\end{array}$ & $\begin{array}{l}\text { Water Communication } \\
\text { Implications and Existing } \\
\text { Research }\end{array}$ \\
\hline Policy & $\begin{array}{l}\text { Water policies range from water } \\
\text { conservation initiatives to } \\
\text { significant infrastructure } \\
\text { decisions (e.g., constructing a } \\
\text { desalination plant); water } \\
\text { markets; and urban planning } \\
\text { policies that affect water use, } \\
\text { urban design, and water's urban } \\
\text { relationship. These policies and } \\
\text { their outcomes communicate to } \\
\text { the public about the }\end{array}$ & $\begin{array}{l}\text { Policy can be considered under } \\
\text { political communication theories, } \\
\text { which explain the process by which } \\
\text { leaders, the media, and the public } \\
\text { "use messages to construct meaning } \\
\text { about political practices," and these } \\
\text { can influence public policy } \\
\text { outcomes (Schuetz, } 2009 \text { p. 1). } \\
\text { When a policy is implemented, } \\
\text { people affected will "construct its } \\
\text { meaning from reflective thinking }\end{array}$ & $\begin{array}{l}\text { Engaging the community to } \\
\text { contribute to water policy } \\
\text { development will be important } \\
\text { under climate change. This field } \\
\text { of communication research can } \\
\text { also advise policymakers on how } \\
\text { to make policy messages relevant } \\
\text { to the public. Water research, } \\
\text { including that by Dean et al. } \\
\text { (2016), seeks to understand how }\end{array}$ \\
\hline
\end{tabular}




\begin{tabular}{|c|c|c|c|}
\hline & $\begin{array}{l}\text { government's views on water. } \\
\text { The design and implementation } \\
\text { of the policy can be planned to } \\
\text { involve the community. }\end{array}$ & $\begin{array}{l}\text { about the policy message that } \\
\text { accounts for the reactions from } \\
\text { their significant others" (Schuetz, } \\
2009 \text { p. 3). In many instances } \\
\text { communication about policy seeks } \\
\text { to engage the public and contribute } \\
\text { to policy recommendations } \\
\text { (Schuetz, 2009). }\end{array}$ & $\begin{array}{l}\text { personal factors influence views } \\
\text { on water policy examples. }\end{array}$ \\
\hline $\begin{array}{l}\text { Communication } \\
\text { campaigns }\end{array}$ & $\begin{array}{l}\text { Water communication } \\
\text { campaigns are designed by } \\
\text { public entities (e.g., } \\
\text { governments and water } \\
\text { authorities) to influence public } \\
\text { attitudes toward water-related } \\
\text { issues of public significance. } \\
\text { They can seek to influence } \\
\text { short- and long-term behavior } \\
\text { change (e.g., water } \\
\text { conservation) or simply } \\
\text { communicate and raise } \\
\text { awareness of water issues. }\end{array}$ & $\begin{array}{l}\text { Communication campaigns employ } \\
\text { a set of communication activities } \\
\text { across a set period of time, seeking } \\
\text { to achieve specific outcomes across } \\
\text { a large number of people (Silk, } \\
\text { 2009). Objectives can include } \\
\text { influencing attitudes, increasing } \\
\text { knowledge, raising awareness, and } \\
\text { behavior change (Silk, } 2009 \text { p. } 2 \text { ). }\end{array}$ & $\begin{array}{l}\text { A significant body of research } \\
\text { within water literature explores } \\
\text { aspects of communication } \\
\text { campaigns. This includes the } \\
\text { understanding of attitudes toward } \\
\text { water issues (Lohman \& } \\
\text { Milliken, 1985), increasing } \\
\text { knowledge of water issues } \\
\text { (Dolnicar, Hurlimann, \& } \\
\text { Nghiem, 2010), and behavior } \\
\text { change (Syme, Nancarrow, \& } \\
\text { Seligman, 2000). Theories } \\
\text { employed to aid such research } \\
\text { include the theory of planned } \\
\text { behavior (Hurlimann et al., } \\
\text { 2009). }\end{array}$ \\
\hline Media & $\begin{array}{l}\text { Media, and in particular mass } \\
\text { media, represents a significant } \\
\text { way in which water messages } \\
\text { have been communicated to the } \\
\text { public. These messages have } \\
\text { been largely government and } \\
\text { water utility messages. The use } \\
\text { of social media to communicate } \\
\text { water issues also occurs. Less }\end{array}$ & $\begin{array}{l}\text { Traditional forms of media include } \\
\text { television, newspapers, books, } \\
\text { radio, movies, and the Internet. } \\
\text { More recent social and } \\
\text { technological advances are } \\
\text { changing the nature of media, } \\
\text { "blurring the lines between } \\
\text { traditional interpersonal } \\
\text { communication and mass } \\
\text { communication" (Pearce, } 2009 \mathrm{p} \text {. }\end{array}$ & $\begin{array}{l}\text { Newspaper framing of water } \\
\text { issues can be an important } \\
\text { influence and has received } \\
\text { research attention in the water } \\
\text { field (Campbell, Smith, \& } \\
\text { Siesmaa, 2011; Hurlimann \& } \\
\text { Dolnicar, 2012). Social media } \\
\text { has been found to be used } \\
\text { effectively by public opposition } \\
\text { groups in opposition to }\end{array}$ \\
\hline
\end{tabular}




\begin{tabular}{|c|c|c|c|}
\hline & $\begin{array}{l}\text { research has been conducted } \\
\text { into this medium. }\end{array}$ & $\begin{array}{l}\text { 2). Media such as newspapers can } \\
\text { be used by certain actors (e.g., } \\
\text { political elites) to frame issues } \\
\text { relevant to government decisions } \\
\text { (Schuetz, 2009). }\end{array}$ & $\begin{array}{l}\text { government plans to implement } \\
\text { new water sources such as water } \\
\text { reuse (Hurlimann \& Dolnicar, } \\
2010 \text { ). }\end{array}$ \\
\hline Culture & $\begin{array}{l}\text { Culture includes the influence } \\
\text { of historical water events and } \\
\text { practices and their influence on } \\
\text { current cultural practices and } \\
\text { experiences of water. }\end{array}$ & $\begin{array}{l}\text { "Culture is a code of speaking and } \\
\text { acting, a historically transmitted } \\
\text { pattern of symbols, meanings, } \\
\text { premises and rules" (Collier, } 2009 \\
\text { p. 5). Some scholars in this field } \\
\text { seek to identify those social } \\
\text { practices that can change. }\end{array}$ & $\begin{array}{l}\text { Culture is a significant influence } \\
\text { on human-water relations. } \\
\text { Understanding water culture will } \\
\text { be important to water } \\
\text { communication, including water } \\
\text { conservation measures. It can } \\
\text { identify which social practices } \\
\text { around water can change and } \\
\text { those which are too important } \\
\text { culturally to change. Such work } \\
\text { includes Allon and Sofoulis } \\
\text { (2006). }\end{array}$ \\
\hline Environment & $\begin{array}{l}\text { Natural and built environments } \\
\text { communicate about water in a } \\
\text { nonverbal way. For example, } \\
\text { the health of natural } \\
\text { environments communicates } \\
\text { about the state of water health. } \\
\text { Open space and green and blue } \\
\text { spaces (or the lack thereof) in } \\
\text { cities communicates the values } \\
\text { of water and its place in cities. } \\
\text { Built infrastructure for water } \\
\text { management communicates } \\
\text { human domination and control } \\
\text { of water and implies a certain } \\
\text { level of water security. } \\
\text { Discourse surrounds water }\end{array}$ & $\begin{array}{l}\text { Some environmental } \\
\text { communication scholars are } \\
\text { interested in how nature } \\
\text { communicates (nonverbally), which } \\
\text { is a significant departure from } \\
\text { traditional communications } \\
\text { research (Milstein, 2009). These } \\
\text { scholars "situate nature as an } \\
\text { integrated and dynamic } \\
\text { communicatory participant that has } \\
\text { a role in mediating human-nature } \\
\text { relations" (Milstein, 2009, p. 5). }\end{array}$ & $\begin{array}{l}\text { The state of the environment due } \\
\text { to drought (e.g., dry) has been } \\
\text { used in water communication } \\
\text { messages (Bell, 2009). } \\
\text { Additionally, research has found } \\
\text { that those living in water-scarce } \\
\text { locations are more supportive of } \\
\text { water conservation initiatives and } \\
\text { are more likely to state they } \\
\text { engage in water conservation } \\
\text { behaviors (Gilbertson, } \\
\text { Hurlimann, \& Dolnicar, 2011). }\end{array}$ \\
\hline
\end{tabular}


